Article

\title{
Are Wildland Fires Increasing Large Patches of Complex Early Seral Forest Habitat?
}

\author{
Dominick A. DellaSala ${ }^{1, *}$ and Chad T. Hanson ${ }^{2}$ \\ 1 Geos Institute, 84-4th St. Ashland, OR 97520, USA \\ 2 Earth Island Institute, 2150 Allston Way, Suite 460, Berkeley, CA 94704, USA \\ * Correspondence: dominick@geosinstitute.org
}

Received: 28 June 2019; Accepted: 30 August 2019; Published: 6 September 2019

\begin{abstract}
High-severity fire creates patches of complex early seral forest (CESF) in mixed-severity fire complexes of the western USA. Some managers and researchers have expressed concerns that large high-severity patches are increasing and could adversely impact old forest extent or lead to type conversions. We used GIS databases for vegetation and fire severity to investigate trends in large ( $>400 \mathrm{ha}$ ) CESF patches in frequent-fire forests of the western USA, analyzing four equal time periods from 1984 to 2015. We detected a significant increase in the total area of large patches relative to the first time period only (1984-1991), but no significant upward trend since the early 1990s. There was no significant trend in the size of large CESF patches between 1984 and 2015. Fire rotation intervals for large CESF patches ranged from 12 centuries to over 4000 years, depending on the region. Large CESF patches were highly heterogeneous, internally creating ample opportunities for fire-mediated biodiversity. Interior patch areas far removed from the nearest low/moderate-severity edges comprised a minor portion of high-severity patches but may be ecologically important in creating pockets of open forest. There was ample historical evidence of large CESF patches but no evidence of increases that might indicate a current risk of ecosystem-type shifts.
\end{abstract}

Keywords: complex early seral forest; conifers; biodiversity; high-severity fire; western USA

\section{Introduction}

High-severity fire patches represent the component in fires that kill all or nearly all of the overstory trees within mixed-severity fire areas in conifer forests of the western USA [1,2], creating a unique forest habitat type known as the complex early seral forest (CESF) [3]. CESFs are distributed as small $(<1 \mathrm{ha}$ ) to large patches ( $>400 \mathrm{ha}$ ) in mixed-severity burns in the lower/middle-montane conifer forests of the Sierra Nevada [2] and within other frequent-fire forest types of the western USA [4-6]. Unlike early seral produced by a clear-cut or otherwise intensively logged area, a CESF is more complex in its structure, and is characterized by a heterogeneous mix of abundant standing dead trees (snags) and downed logs, naturally regenerating conifers, other trees, shrub patches, and abundant wildflowers [3].

Whether high-severity fire is increasing and the ultimate causes of presumed increases (e.g., climate change, increase in tree densities) is the subject of much recent debate. For instance, the areal extent and proportion of high-severity fire within large fire complexes have not changed markedly in recent decades in most forested regions of the West [4,7-11], but results are equivocal in the Rocky Mountains and Southwestern US, e.g., see $[9,11,12]$. In the Sierra Nevada, some studies have reported increasing trends for high-severity fire, e.g., $[13,14]$, whereas subsequent research $[15,16]$ indicated no increases. Moreover, the size of CESF patches within large fire complexes has been used as a key metric to hypothesize whether fire regimes are operating within historical bounds [6,17-21]. Some have expressed concerns that large high-severity patches are increasing as a component of a recent increase in so-called megafires and that this may signal ecosystem-type shifts and the loss of old-growth 
forests $[6,18,20,22]$, while others have predicted potential overall decreases in the future occurrence of high-severity fire in general [23]. Concern over high-severity fires and the resulting large patches of CESF has been a catalyst for fundamental changes to federal forest management policies (e.g., Healthy Forest Restoration Act of 2003, 2012 National Forest Management Act Planning Rule) and has been recently used to promote proposed congressional legislation that would substantially curtail environmental protections and dramatically increase logging in federal forests (e.g., The Resilient Federal Forests Act of 2019). Concerns over high-severity fires overall are missing a biodiversity perspective that is necessary to fully evaluate fire management proposals in the context of ecosystem benefits from such fires and not just their potential impacts on people [24,25].

Notably, patches of CESF support unique fire-adapted communities, including many plants [26], avifauna [27,28], mammals [29], bats [30], terrestrial [31] and aquatic invertebrates [32]. The Black-backed Woodpecker (Picoides arcticus) is associated with large CESF patches (typically 100-800 ha for a single pair, depending on habitat quality) for nesting and foraging [33-36]. The California Spotted Owl (Strix occidentalis occidentalis), which is being petitioned for federal listing under the Endangered Species Act, actively forages in CESF patches $[37,38]$. Thus, policies aimed at suppressing large fires that otherwise would maintain and replenish CESF patches may have unintended consequences for fire-mediated biodiversity [24,25].

Our objectives were to determine whether there has been a recent trend (increase or decrease) in large CESF patches in fire areas within frequent-fire conifer forests of the western USA [4,39], to evaluate the spatiotemporal extent of such patches in these forests, assess their internal heterogeneity, and investigate historical evidence for the occurrence of such patches. Our study is the first to analyze the occurrence of large high-severity fire patches by distinct time periods. Additionally, our findings may have relevance to policy makers and forest-fire managers seeking to integrate biodiversity benefits of large CESF patches with wildfire risk reduction to people and natural resource management $[24,25]$.

\section{Methods}

We analyzed the same western USA frequent-fire forest types, and used the same vegetation databases as in our related study [40] (Figure 1). These areas are dominated by mixed-conifer forests, as well as ponderosa pine (Pinus ponderosa) and Jeffrey pine (Pinus jeffreyi) forests.

We downloaded burn severity maps derived from satellite imagery from the Monitoring Trends in Burn Severity project (MTBS; http://www.mtbs.gov). Within the conifer forests of our study area, we defined CESF patches as areas experiencing high-severity fire, using a threshold of Relative Delta Normalized Burn Ratio (RdNBR) values $\geq 641$ [41]. The same or similar thresholds have been used to define high-severity fire in multiple forest regions of western USA [21,42-44] and thus, our findings are directly applicable with consistent use of MTBS across studies. Although there is no accepted or standard definition of large CESF patches, we chose to analyze patches $>400$ ha in order to address concerns expressed by researchers that CESF patches hundreds of hectares or larger may not have occurred historically $[6,18,21]$, may create homogeneity and inhibit post-fire forest regeneration due to lack of seed sources [20,22] and/or may reduce forest resilience to climate change [45-47]. We used an inclusive approach such that any high-severity fire pixels of conifer forest $(30 \times 30-\mathrm{m}$ each) with sides touching were considered to be part of the same patch.

We used a Mann-Kendall test to determine whether there is any trend in (a) the combined total annual area of CESF patches $>400 \mathrm{ha}$, and (b) the size of individual CESF patches $>400$ ha, for the years 1984-2015 (the period for which consistently mapped MTBS datasets were available for the US), analyzing both the annual area of large CESF patches, and the size of individual large CESF patches, as continuous variables. Mann-Kendall is a non-parametric test for monotonic upward or downward trends over time and has been used in similar studies $[9,15,48]$. Compared to other tests, including parametric tests, the Mann-Kendall has been found to have an equal or greater statistical power to detect trends in environmental time series data when the data are non-parametric, such as wildland fire trend data [15]. 


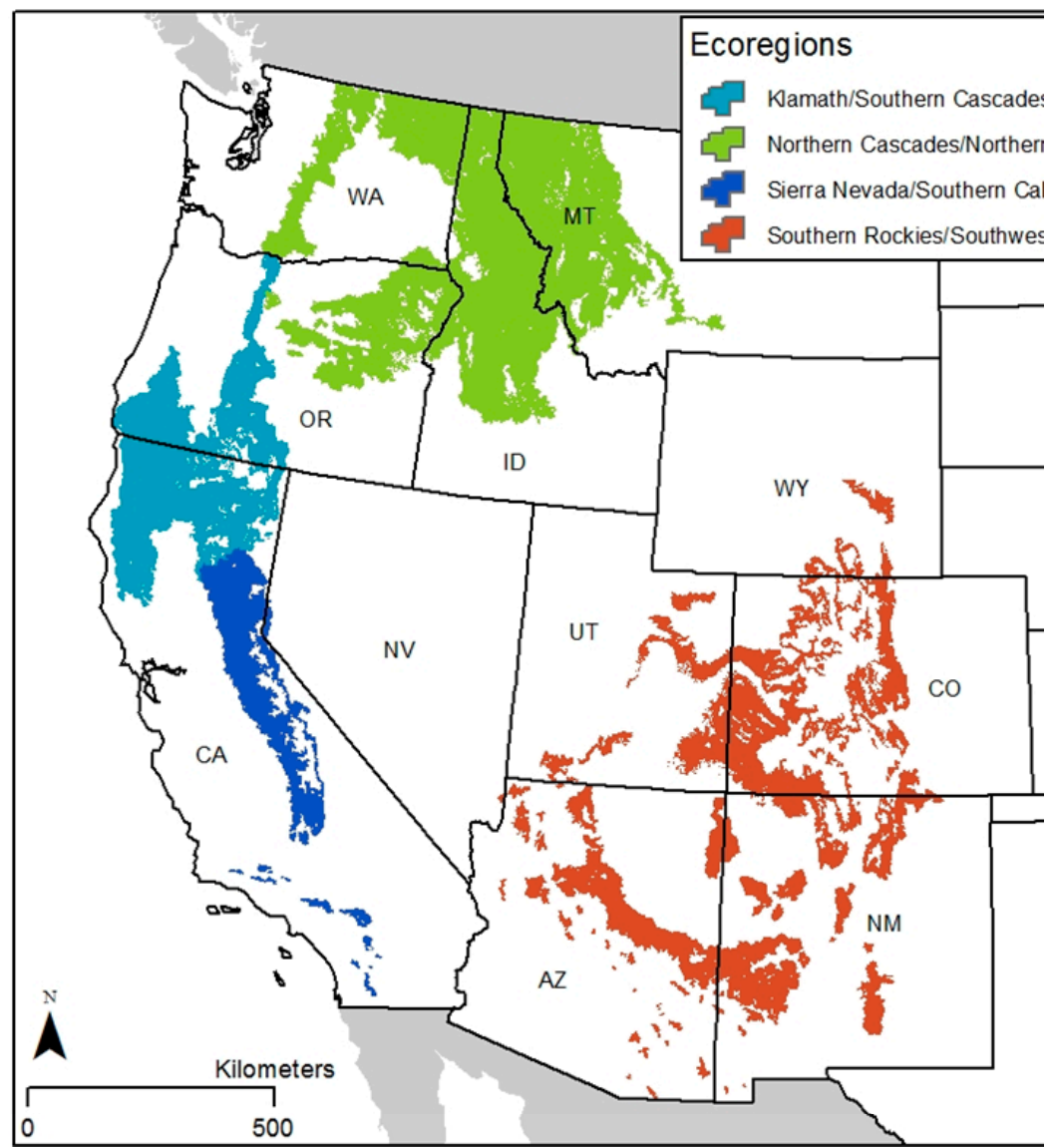

Figure 1. Ecoregions with pine and mixed conifer forests analyzed for large high-severity fire patches in our study modified from [40]. Two-letter acronyms shown on the map represent different U.S. states.

Since we were interested in determining the specific timing of any differences in occurrence in large CESF patches, we used a Nemenyi non-parametric test for multiple comparisons among groups with an equal sample size [49] to analyze whether there have been increases or decreases in large ( $>400$ ha) patches of CESF, created by high-severity fire, for total annual area across four equal time periods (1984-1991, 1992-1999, 2000-2007, 2008-2015). To determine which specific time groups were significantly different with regard to individual patch sizes, we used a Dunn non-parametric test for multiple comparisons with unequal sample sizes [49]. In all analyses, significance was assessed at $\alpha=$ 0.05 . We conducted this analysis because we wanted to determine whether any trend in the occurrence of large CESF patches is current and ongoing or happened at some point in the past, during the 1984-2015 time series, but may not be ongoing. This is not possible when large CESF patch occurrence is analyzed as continuous variables across the entire time series. For these two multiple comparison analyses, we chose to assess four groups of eight years each, rather than, for example, eight groups of four years each because the latter reduces sample size within each group to levels considered to be statistically inadvisable, and because using eight groups of four years increases the critical threshold to determine differences among groups, thus making it more difficult to reveal such differences when they exist [49].

In order to understand the spatiotemporal extent and context of large CESF patches across the forested landscape, we calculated fire rotation intervals [9] for high-severity fire patches $>400$ ha in each of four regions in the western USA: Sierra-Nevada/Southern-California, Klamath/Southern-Cascades, Northern-Cascades/Northern-Rockies, and Southern-Rockies/Southwest. The rotation interval for the occurrence of large CESF patches is equal to the average interval between occurrences of large patches across the study landscape [9]. 
We also analyzed the internal heterogeneity of CESF patches $>400$ ha in the four western USA regions by determining the percentage of the total area of such patches that was 1-100 $\mathrm{m}, 101-200 \mathrm{~m}$, 201-300 m, and $>300 \mathrm{~m}$ from the nearest unburned, low, or moderate-severity pixel (from either outside or inside the patch) within the frequent-fire conifer forest types analyzed in this study [40]. We included a specific analysis of internal heterogeneity of large high-severity patches because some authors have hypothesized that such patches would be internally homogeneous and have expressed concern about the potential for natural succession in this regard $[6,20]$. The distance intervals selected for this analysis were based on biologically meaningful relationships in levels of natural post-fire conifer regeneration at increasing distances from seed sources. We assumed lower levels of conifer recruitment at greater distances from live trees, consistent with natural succession to more open forest conditions [45,50-53].

Finally, although it was beyond the scope of this study to attempt to compare current versus historical rates of occurrence of large CESF patches, we included a table summarizing evidence for historical occurrence of patches $>400$ ha, focusing on low/middle-montane, frequent-fire forest types, given questions expressed about whether large CESF patches occurred historically in these forests $[6,18,21]$.

\section{Results}

Over the entire time series, 1984-2015, there was a significant increasing trend in the combined total area of CESF patches $>400$ ha in each year $(\tau=0.407, p=0.001)$, but no trend in patch size $(\tau=0.009, p=0.802)$. However, when the data were analyzed by time periods, there was only one significant difference in the annual area of CESF habitat created by high-severity fire relative to the earliest time period (1984-1991), but no significant differences were detected among time periods since the early 1990s (Table 1, Figure 2). With regard to the size of individual large CESF patches, there were no significant differences detected among time periods (Table 2). Figure 3 shows the distribution of individual large CESF patches over the entire time series.

Table 1. Critical values $\left(\mathrm{q}_{0.05,4}\right)$, absolute difference between mean of ranks $\left(\left|R_{\mathrm{A}}-R_{\mathrm{B}}\right|\right)$, standard errors (SE), and test statistics (q) to assess statistical significance, at $\alpha=0.05$ of any differences among the four time groups $(1=1984-1991,2=1992-1999,3=2000-2007$, and $4=2008-2015)$ for total annual area of CESF patches $>400$ ha using the Nemenyi non-parametric test for multiple comparisons between groups with an equal sample size ( $n=8$ years for each time group). The statistical significance of the levels of q are shown as " $\mathrm{Y}$ " (significant) or " $\mathrm{N}$ " (not significant).

\begin{tabular}{cccccc}
\hline $\begin{array}{c}\text { Time Group } \\
\text { Comparison }\end{array}$ & $\mathbf{q}_{\mathbf{0 . 0 5 , 4}}$ & $\left|\boldsymbol{R}_{\mathbf{A}}-\boldsymbol{R}_{\mathbf{B}}\right|$ & SE & $\mathbf{q}$ & $\begin{array}{c}\text { Significant? } \\
\text { (Is q }>\mathbf{q}_{\mathbf{0 . 0 5}, \mathbf{4}} \text { ?) }\end{array}$ \\
\hline $1-2$ & 3.63 & 45.0 & 26.53 & 1.70 & $\mathrm{~N}$ \\
\hline $1-3$ & 3.63 & 108.0 & 26.53 & 4.07 & $\mathrm{Y}$ \\
\hline $1-4$ & 3.63 & 107.0 & 26.53 & 4.03 & $\mathrm{Y}$ \\
\hline $2-3$ & 3.63 & 63.0 & 26.53 & 2.37 & $\mathrm{~N}$ \\
\hline $2-4$ & 3.63 & 62.0 & 26.53 & 2.34 & $\mathrm{~N}$ \\
\hline $3-4$ & 3.63 & 1.00 & 26.53 & 0.04 & $\mathrm{~N}$ \\
\hline
\end{tabular}




\section{High Severity Patches > 400ha}

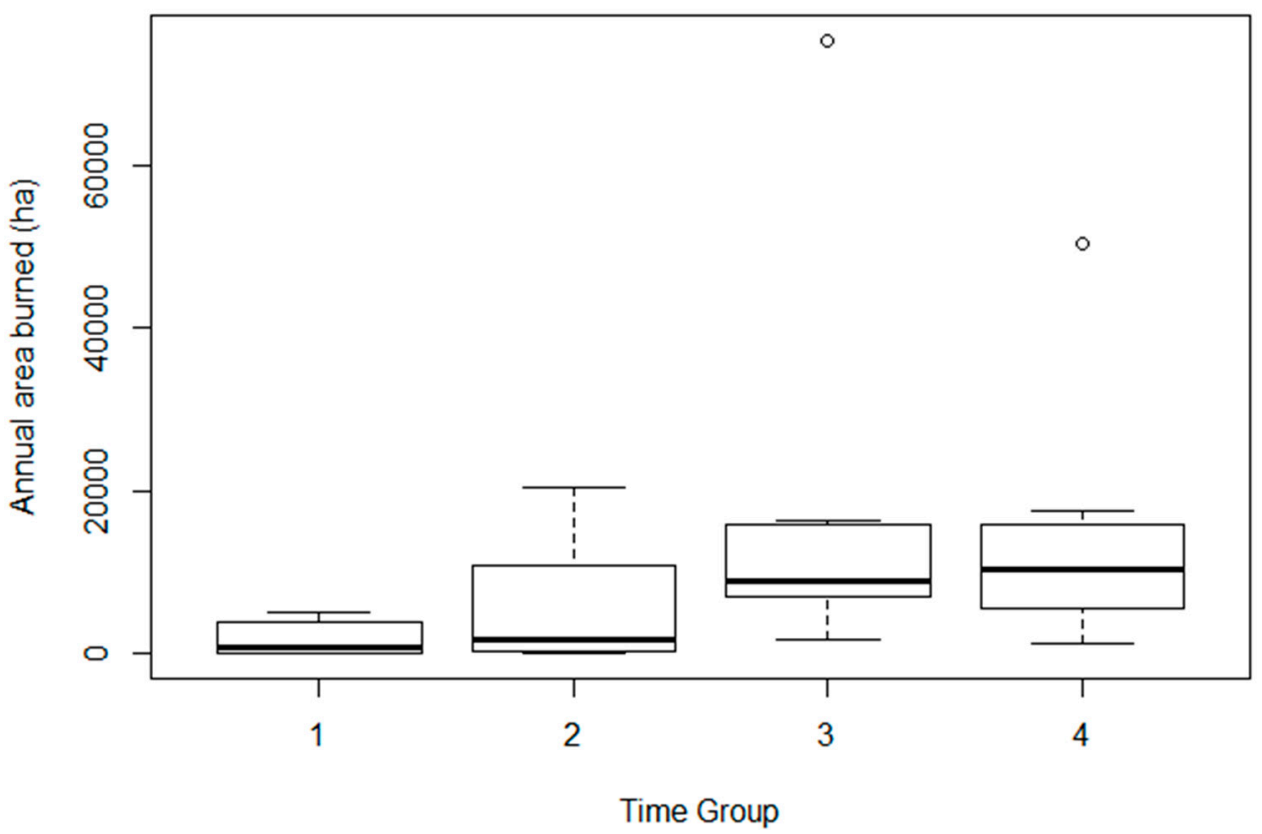

Figure 2. Annual area of large ( $>400$ ha) CESF patches in the four time periods (see Tables 1 and 2 for time periods).

Table 2. Critical values $\left(\mathrm{q}_{0.05,4}\right)$, absolute difference between mean of ranks. $\left(\left.\right|_{\mathrm{A}}{ }^{-B} \mid\right)$, standard errors (SE), and test statistics (Q) to assess statistical significance at $\alpha=0.05$ of any differences among the four-time groups $(1=1984-1991,2=1992-1999,3=2000-2007$, and $4=2008-2015)$ for the size of individual CESF patches $>400$ ha using the Dunn non-parametric test for multiple comparisons. The statistical significance of levels of $\mathrm{Q}$ are shown as " $\mathrm{Y}$ " (significant) or "N" (not significant). For time groups $1,2,3$, and $4, \mathrm{n}=17,46,134$, and 130 CESF patches $>400$ ha, respectively.

\begin{tabular}{cccccc}
\hline $\begin{array}{c}\text { Time Group } \\
\text { Comparison }\end{array}$ & $\mathbf{Q}_{0.05,4}$ & IA-B $_{\mathrm{B}}$ & SE & $\mathbf{Q}$ & $\begin{array}{c}\text { Significant? } \\
\text { (Is } \mathbf{Q}>\mathbf{Q}_{\mathbf{0 . 0 5}, \mathbf{4}} \text { ?) }\end{array}$ \\
\hline $1-2$ & 2.64 & 2.73 & 26.91 & 0.10 & $\mathrm{~N}$ \\
\hline $1-3$ & 2.64 & 26.50 & 24.37 & 1.09 & $\mathrm{~N}$ \\
\hline $1-4$ & 2.64 & 15.08 & 24.42 & 0.62 & $\mathrm{~N}$ \\
\hline $2-3$ & 2.64 & 23.77 & 16.23 & 1.46 & $\mathrm{~N}$ \\
\hline $2-4$ & 2.64 & 12.35 & 16.29 & 0.76 & $\mathrm{~N}$ \\
\hline $3-4$ & 2.64 & 11.42 & 11.60 & 0.98 & $\mathrm{~N}$ \\
\hline
\end{tabular}

Over the 32-year study period, high-severity fire patches $>400$ ha occurred on $\sim 0.7 \%$ to $\sim 2.7 \%$ of the total area of frequent-fire conifer forest, depending on the region, such that the rotation intervals for occurrence of large ( $>400$ ha) CESF patches, created by high-severity fire, ranged from 1181 years to 4354 years (Table 3 ). 
Table 3. Total area and fire rotation interval for occurrence of CESF patches $>400$ ha in the four regions of the study area from 1984 to 2015.

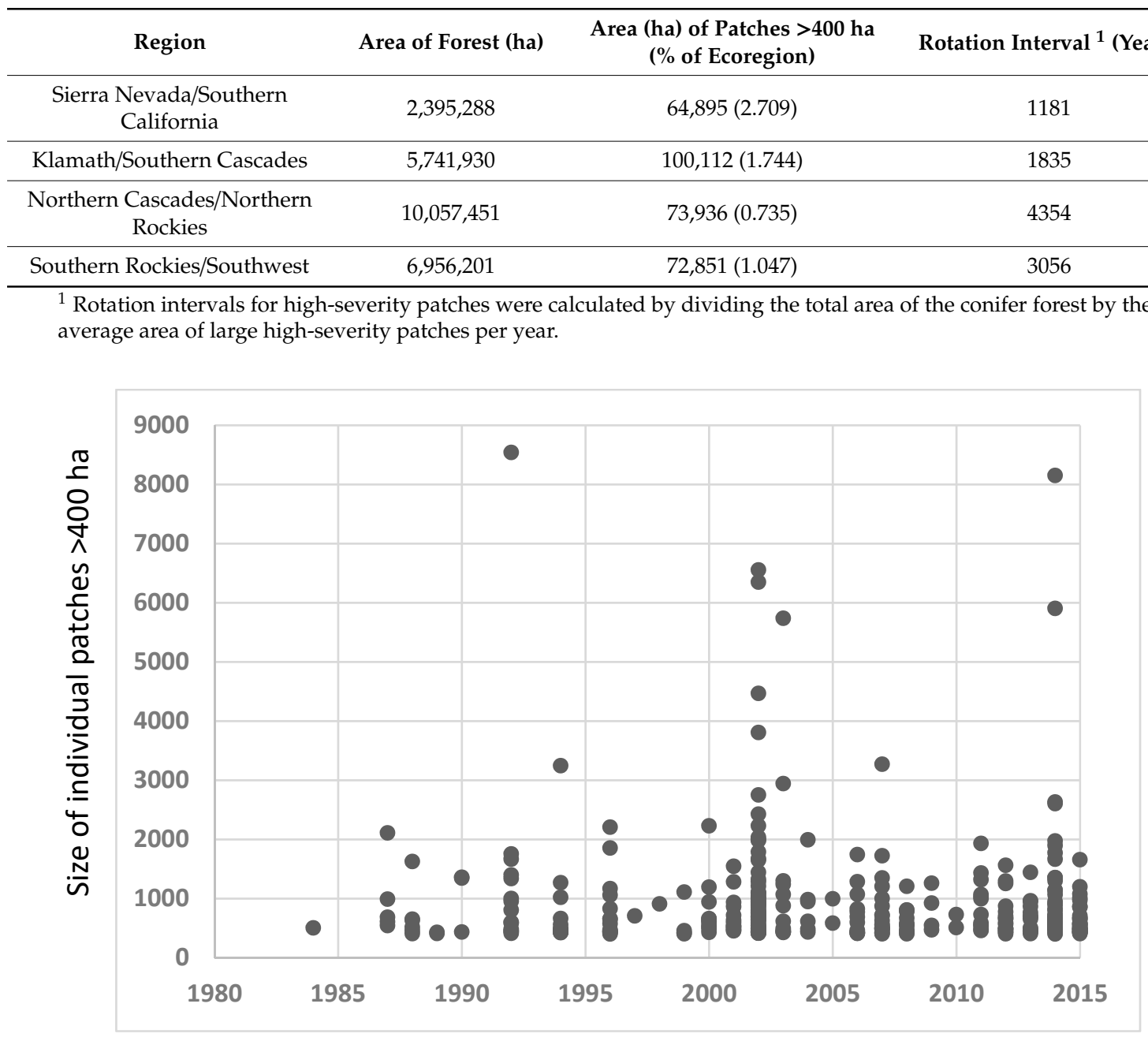

Figure 3. Scatter plot of size of individual large (>400 ha) CESF patches, 1984-2015.

Overall, $52 \%$ of the area within the boundaries of CESF patches $>400$ ha was within $100 \mathrm{~m}$ of unburned, low, or moderate-severity edges/inclusions, and $78 \%$ of the total area was within $200 \mathrm{~m}$ of such edges and inclusions. The results were similar in all four western USA regions (Table 4). Figure $\mathrm{S} 1$ is an example illustration of various distances from potential seed sources in very large ( $>1000 \mathrm{ha})$ high-severity patches in two areas: Rim fire 2013 (Stanislaus National Forest, Sierra Nevada, CA) and Hayman Fire 2002 (northwest Colorado Springs area).

Table 4. Percentages of the total area within the boundaries of CESF patches $>400$ ha, created by high-severity fire, that were at increasing distances from unburned or low/moderate-severity edges and inclusions.

\begin{tabular}{ccccc}
\hline Distance (m) & $\begin{array}{c}\text { Sierra-Nevada/ } \\
\text { Southern-California }\end{array}$ & $\begin{array}{c}\text { Klamath/ } \\
\text { Southern-Cascades }\end{array}$ & $\begin{array}{c}\text { Northern-Cascades/ } \\
\text { Northern-Rockies }\end{array}$ & $\begin{array}{c}\text { Southern-Cascades/ } \\
\text { Southwest }\end{array}$ \\
\hline$<100$ & 49.3 & 55.6 & 46.8 & 54.7 \\
\hline $101-200$ & 27.6 & 25.5 & 25.2 & 26.0 \\
\hline $201-300$ & 13.5 & 11.2 & 12.8 & 10.6 \\
\hline$>300$ & 9.6 & 7.7 & 15.3 & 8.7 \\
\hline
\end{tabular}


There is historical evidence of numerous large CESF patches created by high-severity fire prior to widespread fire suppression in every region of the western USA in low/middle-montane forests (Table 5). Historical patches $>400$ ha ranged from $\sim 400$ ha to $>20,000$ ha for our study area.

Table 5. Examples of historical occurrence of CESF patches $>400$ ha, created by high-severity fire, in low/middle-montane forests of the western USA ${ }^{1}$.

\begin{tabular}{|c|c|c|c|c|c|}
\hline Source & Region & Forest Type & Evidence Type & Patch Size/s (ha) & Time Period \\
\hline$[54,55]$ & $\begin{array}{c}\text { Northern Sierra } \\
\text { Nevada }\end{array}$ & $\begin{array}{l}\text { Mixed-conifer and } \\
\text { ponderosa pine }\end{array}$ & $\begin{array}{c}\text { Historical USGS } \\
\text { mapping, and current } \\
\text { GIS analysis }\end{array}$ & $400-\sim 9000$ & 19th century \\
\hline [8] & Sierra Nevada & $\begin{array}{l}\text { Mixed-conifer and } \\
\text { ponderosa pine }\end{array}$ & $\begin{array}{l}\text { Reconstruction, using } \\
\text { 19th-century General } \\
\text { Land Office data }\end{array}$ & $\begin{array}{c}\text { Largest }=8050 \\
\text { (northern) and } 9400 \\
\text { (southern) }\end{array}$ & 19th century \\
\hline [56] & $\begin{array}{c}\text { Eastern Washington } \\
\text { Cascades }\end{array}$ & Mixed-conifer & $\begin{array}{l}\text { Reconstructions of past } \\
\text { high-severity from } \\
\text { historical aerial photos }\end{array}$ & $400-10,500$ & $\begin{array}{l}\text { 19th century, } \\
\text { and early } 20 \text { th }\end{array}$ \\
\hline [57] & $\begin{array}{c}\text { Eastern Oregon } \\
\text { Cascades }\end{array}$ & $\begin{array}{l}\text { Mixed-conifer and } \\
\text { ponderosa pine }\end{array}$ & $\begin{array}{l}\text { Reconstruction from } \\
\text { 19th-century General } \\
\text { Land Office data }\end{array}$ & $400-\sim 5000$ & 19th century \\
\hline [58] & Oregon Klamath & $\begin{array}{l}\text { Mostly ponderosa } \\
\text { pine }\end{array}$ & $\begin{array}{l}\text { Historical account, early } \\
\text { 20th century U.S. } \\
\text { Geological Survey report }\end{array}$ & $\sim 14,000$ & 19th century \\
\hline [59] & Colorado Front Range & $\begin{array}{l}\text { Mostly ponderosa } \\
\text { pine }\end{array}$ & $\begin{array}{l}\text { Reconstruction from } \\
\text { 19th-century General } \\
\text { Land Office data }\end{array}$ & $400-\sim 22,000$ & 19th century \\
\hline [59] & $\begin{array}{l}\text { Blue Mountains, } \\
\text { Oregon }\end{array}$ & Ponderosa pine & $\begin{array}{l}\text { Reconstruction from } \\
\text { 19th-century General } \\
\text { Land Office data }\end{array}$ & $400-\sim 12,000$ & 19th century \\
\hline [59] & $\begin{array}{c}\text { Central/eastern } \\
\text { Arizona }\end{array}$ & Ponderosa pine & $\begin{array}{l}\text { Reconstruction from } \\
\text { 19th-century General } \\
\text { Land Office data }\end{array}$ & $400-\sim 40,000$ & 19th century \\
\hline$[60]$ & $\begin{array}{c}\text { Black Hills, South } \\
\text { Dakota }\end{array}$ & $\begin{array}{c}\text { Ponderosa pine, } \\
\text { some lodgepole pine }\end{array}$ & Historical account & $\sim 19,000$ & $\begin{array}{l}\text { mid-19th } \\
\text { century }\end{array}$ \\
\hline$[61,62]$ & Northern Rockies & $\begin{array}{l}\text { Ponderosa pine, } \\
\text { some Douglas-fir }\end{array}$ & $\begin{array}{l}\text { Reconstruction from } \\
\text { historical aerial photos }\end{array}$ & $\sim 35,000$ & 1910 \\
\hline
\end{tabular}

${ }^{1}$ Some patches may have resulted from more than one fire. This represents all available data on historical occurrence of high-severity fire patches $>400$ ha known to currently exist within western US frequent-fire conifer forest types. For context, the largest individual high-severity fire patches in each of the four current time periods analyzed in this study are (in chronological order, by time period) 2109, 8539, 6554, and 8153 ha.

\section{Discussion}

Despite concerns about there being too many large CESF patches produced by big fires, we found that while an increase in the total area of such patches did occur initially in the time series, this happened over two decades ago and there has been no subsequent increase since the 1990s. We did not find an increase in the size of individual CESF patches $>400$ ha at any point during the time series (1984-2015)—i.e., patches $>400$ ha did not get significantly larger in more recent time periods. The rotation intervals for large patches ranged from about twelve centuries to over four millennia, depending on the region. A posteriori, we conducted the same analyses regarding whether there had been an increase in the area of large high-severity fire patches, but with a smaller patch size threshold $(>100 \mathrm{ha})$, and we found the same result-i.e., significant differences between the first time period and the third and fourth time periods, but no other significant differences (Table S1, Figure S2). We did not conduct a posteriori analysis for patches $>100$ ha regarding the question of whether individual high-severity patches had been getting larger, since there were no significant or marginally significant differences with the $>400$ ha threshold.

Importantly, in large CESF patches, within-patch heterogeneity was high, with the great majority of patch area occurring within $200 \mathrm{~m}$ of the potential seed sources of unburned, low, or moderately burned conifer forest. In this regard, our findings are similar to those in the Northern US Rockies [63]. Depending on site factors, natural post-fire conifer regeneration generally occurs most quickly and abundantly within $100 \mathrm{~m}$ of low/moderate-severity and unburned recruitment areas, and secondarily at 100-200 m from unburned or low/moderate-severity areas [45,50-53,64]. It also occurs-typically 
more slowly and less densely - in the portion of large CESF patches that are $>200 \mathrm{~m}$ from unburned or low/moderate-severity areas $[51,53,64]$. However, in these more distant areas, we can expect pockets of more open conifer forest or dense vegetation dominated primarily by oaks (Quercus spp.) and aspen (Populus spp.) and secondarily by conifers [51,64]. This internal patch heterogeneity indicates that large CESF patches play an important role in creating and maintaining pockets of open forest stands and increasing the heterogeneity (beta diversity) of forest structure across the landscape [64].

We also found considerable evidence of historical occurrence of large CESF patches in all regions, indicating that such patches are a component of natural fire regimes in low/middle-elevation, frequent-fire conifer forests of the western USA. More research is needed to compare current versus historical extents of such patches.

Modeling studies regarding wildland fire in western forests project overall increases [65], or more complex mixes of increases and decreases within and among regions, mediated by interactions between climate and vegetation shifts [65-67]. Thus, it will be important to continue to monitor high-severity fire occurrence and patch sizes periodically to understand any patterns that emerge in patch dynamics and conifer recruitment rates. Our findings also differ from some previous work regarding high-severity fire trends in western U.S. conifer forests. Some researchers [13,14], for instance, noted increasing trends in overall high-severity fire occurrence in mixed-conifer forests of the Sierra Nevada. Subsequent analyses $[15,16]$ found that the use of a vegetation database by these researchers post-dated the time series being analyzed and led to an unintended omission of much of the high-severity fire in the earlier years of the time series, causing the appearance of an upward trend where no such trend existed. In other words, it was later found that the vegetation database used by these studies often did not reflect the vegetation that existed at the time of the fires analyzed, since much of the conifer forest that experienced high-severity fire in the earlier years of the time series was later reclassified as chaparral or other non-conifer vegetation-a phenomenon that occurred less for more recent fires in the time series.

Others $[46,68,69]$ reported an increasing trend in the interior area of high-severity fire patches in the Sierra Nevada, but also used a vegetation database that post-dated the time series and omitted more of the high-severity fire in the earlier years of the time series [15]. They did not account for small low/moderate-severity inclusions within large high-severity fire patches, while inclusions of this size were common in our analyses.

Our results indicate that large CESF patches have high levels of heterogeneity (beta diversity), even within the most interior portions, which may facilitate heterogeneous natural forest regeneration in ecologically beneficial ways $[25,53,55,70]$. Some delayed tree mortality can, of course, occur in the years following a fire in low/moderate-severity inclusions, and this could potentially influence the internal patch complexity along with conifer seedling establishment. Yet, even in such cases, individual trees experiencing delayed mortality would provide seed source in the interim years, and research into delayed post-fire mortality indicates fairly modest levels of such occurrences in low/moderate-severity pixels [71].

Some researchers have expressed concern about type conversion to non-forest following fires, especially high-severity fires, e.g., $[47,72]$. Although a detailed discussion of this issue is beyond the scope of our study, we note that areas described as examples of possible post-fire type conversion nevertheless had substantial post-fire conifer regeneration, generally within the described natural range of variability for the specific forest type [72], and the areas with no regeneration occurred at the spatial scale of very small plots $[47,72]$. Thus, we suggest that there may be a scale-of-observation issue at work here, and much larger plots indicate more consistent post-fire regeneration [64]. Moreover, while recent research has suggested somewhat lower regeneration in more recent fires, time-since-fire was not accounted for, and far fewer years of post-fire succession had occurred at the time of field sampling in the more recent fires, which might account for the difference [47]. Nevertheless, some researchers have predicted that in a hotter and drier climate in certain areas, such as the Klamath region of northwestern California, recurrent high-severity fire could limit the recruitment of some 
conifer species in future decades [73]. Thus, more research is needed to address this question after taking spatial and temporal scale and time-since-fire into account.

\section{Conclusions}

Our findings have specific management and policy relevance. In particular, we counter claims made by some researchers, and often used by decision-makers, to justify large-scale forest "thinning" and post-fire logging projects-specifically, the assumption that such logging projects are needed to prevent type conversion in response to a perceived increase in CESF patch sizes and conifer regeneration failures in "megafires" (see $[6,18,20,22])$. Lack of a biodiversity perspective has created underlying tensions among researchers over the role of high-severity fires in maintaining CESF, and we hope that our findings will now inform this ongoing discussion. Additionally, contrary to assumptions made by land managers in the course of proposing extensive post-fire logging and creation of artificial tree plantations following large fires, we found ample evidence of patch heterogeneity-and presumably natural conifer establishment-in large severely burned patches, in addition to the occurrence of large high-severity patches in the historical record. This finding has key relevance to current forest management policy, since the assertion that current large CESF patches are unprecedented is not substantiated by our data but is being used to justify legislative and regulatory proposals to severely weaken environmental laws on U.S. federal lands.

Notably, numerous studies have found high levels of native plant and animal richness and abundance in large fires of mixed severity that produce CESF patches in severely burned areas, see $[3,24-31,70,74,75]$. Such fires facilitate high levels of beta diversity at landscape scales, providing a broad suite of habitat for both fire-seeking and fire-avoiding species [25], including many early seral birds that have been declining due to a lack of "diverse early seral habitat" [76]. Thus, far from being indicative of "catastrophic" (or "megafire") ecosystem shifts, large CESF patches have consistently been found to support a unique ecological community that is otherwise most often post-fire logged because of perceptions that this forest type has limited wildlife value, see [25,75]. Instead, we found that large CESF patches are extremely infrequent at landscape scales in ponderosa/Jeffrey-pine and mixed-conifer forests of the western U.S., and whether high-severity fire that produces this important seral stage is increasing in western USA forests remains debatable, e.g., [4,9-11,13-16,19,21,23].

Regarding the human implications of our findings, we recommend that land managers focus limited resources on community fire safety and defensible space of homes as a means of getting to coexistence with wildfire [77-79] and for managing wildfire under safe conditions for a myriad of ecosystem benefits.

Supplementary Materials: The following are available online at http://www.mdpi.com/1424-2818/11/9/157/s1: Figure S1: Example of CESF patches $>1,000$ ha, showing distances from areas of unburned, low, and moderate severity fire within the patch boundaries in the Rim (Stanislaus National Forest, CA) and Hayman fires (Colorado Front Range). Figure S2: Annual area of large patches (>100 ha) of CESF in the four time periods; Table S1: Critical values $\left(\mathrm{q}_{0.05, \infty, 4}\right)$, absolute difference between mean of ranks $\left(\left|R_{\mathrm{A}}-R_{\mathrm{B}}\right|\right)$, standard errors (SE), and test statistics $(\mathrm{q})$ to assess statistical significance, at $\alpha=0.05$ of any differences between the four time groups $(1=1984-1991,2=$ 1992-1999, $3=2000-2007$, and $4=2008-2015$ ) for total annual area of CESF patches $>100$ ha using the Nemenyi non-parametric test for multiple comparisons between groups with an equal sample size $(n=8$ years for each time group). The statistical significance of levels of $q$ is shown as $\mathrm{Y}$ (significant) or N (not significant).

Author Contributions: D.A.D. and C.T.H. were equally involved in all aspects of this study.

Funding: We thank the Leonardo DiCaprio Foundation, the Weeden Foundation, and the Wilburforce Foundation for project funding; however, the views herein are strictly those of the authors.

Acknowledgments: Curtis Bradley, Center for Biological Diversity, did all the GIS analyses and project mapping. We thank 3 anonymous reviewers and the journal editors for improvements to the manuscript and Randi Spivak, Center for Biological Diversity, for policy implications of our findings.

Conflicts of Interest: We declare no conflict of interest. The funders had no role in the design of the study; in the collection, analyses, or interpretation of data; in the writing of the manuscript, or in the decision to publish the results. 


\section{References}

1. Quayle, B. Calibration and Validation of Immediate Post-Fire Satellite-Derived Data to Three Severity Metrics. Fire Ecol. 2015, 11, 12-30.

2. Lydersen, J.M.; Collins, B.M.; Miller, J.D.; Fry, D.L.; Stephens, S.L. Relating fire-caused change in forest structure to remotely sensed estimates of fire severity. Fire Ecol. 2016, 12, 99-116. [CrossRef]

3. Dellasala, D.A.; Bond, M.L.; Hanson, C.T.; Hutto, R.L.; Odion, D.C. Complex Early Seral Forests of the Sierra Nevada: What are They and How Can They Be Managed for Ecological Integrity? Nat. Areas J. 2014, 34, 310-324. [CrossRef]

4. Odion, D.C.; Hanson, C.T.; Arsenault, A.; Baker, W.L.; Dellasala, D.A.; Hutto, R.L.; Klenner, W.; Moritz, M.A.; Sherriff, R.L.; Veblen, T.T.; et al. Examining Historical and Current Mixed-Severity Fire Regimes in Ponderosa Pine and Mixed-Conifer Forests of Western North America. PLoS ONE 2014, 9, e87852. [CrossRef]

5. Odion, D.C.; Hanson, C.T.; Baker, W.L.; Dellasala, D.A.; Williams, M.A. Areas of Agreement and Disagreement Regarding Ponderosa Pine and Mixed Conifer Forest Fire Regimes: A Dialogue with Stevens et al. PLoS ONE 2016, 11, e0154579. [CrossRef]

6. Stevens, J.T.; Safford, H.D.; North, M.P.; Fried, J.S.; Gray, A.N.; Brown, P.M.; Dolanc, C.R.; Dobrowski, S.Z.; Falk, D.A.; Farris, C.A.; et al. Average stand age from forest inventory plots does not describe historical fire regimes in ponderosa pine and mixed-conifer forests of western North America. PLoS ONE 2016, 11, e0147688. [CrossRef]

7. Hanson, C.T.; Odion, D.C.; Dellasala, D.A.; Baker, W.L. Overestimation of Fire Risk in the Northern Spotted Owl Recovery Plan. Conserv. Boil. 2009, 23, 1314-1319. [CrossRef]

8. Baker, W.L. Historical forest structure and fire in Sierran mixed-conifer forests reconstructed from General Land Office survey data. Ecosphere 2014, 5, 1-70. [CrossRef]

9. Baker, W.L. Are High-Severity Fires Burning at Much Higher Rates Recently than Historically in Dry-Forest Landscapes of the Western USA? PLOS ONE 2015, 10, e0136147.

10. Law, B.; Waring, R. Carbon implications of current and future effects of drought, fire and management on Pacific Northwest forests. For. Ecol. Manag. 2015, 355, 4-14. [CrossRef]

11. Keyser, A.; Westerling, A. Climate drives inter-annual variability in probability of high severity fire occurrence in the western United States. Environ. Res. Lett. 2017, 12, 65003. [CrossRef]

12. Dillon, G.K.; Holden, Z.A.; Morgan, P.; Crimmins, M.A.; Heyerdahl, E.K.; Luce, C.H. Both topography and climate affected forest and woodland burn severity in two regions of the western US, 1984 to 2006. Ecosphere 2011, 2, 1-33. [CrossRef]

13. Miller, J.D.; Safford, H.D.; Crimmins, M.; Thode, A.E. Quantitative evidence for increasing forest fire severity in the Sierra Nevada and Southern Cascade Mountains, California and Nevada, USA. Ecosystems 2009, 12, 16-32. [CrossRef]

14. Mallek, C.; Safford, H.D.; Viers, J.; Miller, J.D. Modern departures in fire severity and area vary by forest type, Sierra Nevada and Southern Cascades, USA. Ecosphere 2013, 4, 1-28. [CrossRef]

15. Hanson, C.T.; Odion, D.C. Is fire severity increasing in the Sierra Nevada, California, USA? Int. J. Wildland Fire 2014, 23, 1-8. [CrossRef]

16. Hanson, C.T.; Odion, D.C. Sierra Nevada fire severity conclusions are robust to further analysis: A reply to Safford et al. Int. J. Wildland Fire 2015, 24, 294-295. [CrossRef]

17. Stephens, S.L. Forest fire causes and extent on United States Forest Service lands. Int. J. Wildland Fire 2005, 14, 213. [CrossRef]

18. Stephens, S.L.; Agee, J.K.; Fulé, P.Z.; North, M.P.; Romme, W.H.; Swetnam, T.W.; Turner, M.G. Managing Forests and Fire in Changing Climates. Science 2013, 342, 41-42. [CrossRef]

19. Lydersen, J.M.; North, M.P.; Collins, B.M. Severity of an uncharacteristically large wildfire, the Rim Fire, in forests with relatively restored frequent fire regimes. For. Ecol. Manag. 2014, 328, 326-334. [CrossRef]

20. Hessburg, P.F.; Churchill, D.J.; Larson, A.J.; Haugo, R.D.; Miller, C.; Spies, T.A.; North, M.P.; Povak, N.A.; Belote, R.T.; Singleton, P.H.; et al. Restoring fire-prone Inland Pacific landscapes: Seven core principles. Landsc. Ecol. 2015, 30, 1805-1835. [CrossRef]

21. Reilly, M.J.; Dunn, C.J.; Meigs, G.W.; Spies, T.A.; Kennedy, R.E.; Bailey, J.D.; Briggs, K. Contemporary patterns of fire extent and severity in forests of the Pacific Northwest, USA (1985-2010). Ecosphere 2017, 8, e01695. [CrossRef] 
22. Hessburg, P.F.; Spies, T.A.; Perry, D.A.; Skinner, C.N.; Taylor, A.H.; Brown, P.M.; Stephens, S.L.; Larson, A.J.; Churchill, D.J.; Povak, N.A.; et al. Tamm review: Management of mixed-severity fire regime forests in Oregon, Washington, and Northern California. For. Ecol. Manag. 2016, 366, 221-250. [CrossRef]

23. Parks, S.A.; Miller, C.; Abatzoglou, J.T.; Holsinger, L.M.; Parisien, M.-A.; Dobrowski, S.Z. How will climate change affect wildland fire severity in the western US? Environ. Res. Lett. 2016, 11, 35002. [CrossRef]

24. DellaSala, D.A.; Hanson, C.T. Ecological and biodiversity benefits of mega-fires. In The Ecological Importance of Mixed-Severity Fires: Nature's Phoenix; DellaSala, D.A., Hanson, C.T., Eds.; Elsevier: Waltham, MA, USA, 2015; pp. 23-54.

25. Baker, W.L. Accommodating Mixed-Severity Fire to Restore and Maintain Ecosystem Integrity with a Focus on the Sierra Nevada of California, USA. Fire Ecol. 2017, 13, 148-171.

26. Donato, D.C.; Fontaine, J.B.; Robinson, W.D.; Kauffman, J.B.; Law, B.E. Vegetation response to a short interval between high-severity wildfires in a mixed-evergreen forest. J. Ecol. 2009, 97, 142-154. [CrossRef]

27. Fontaine, J.B.; Donato, D.C.; Robinson, W.D.; Law, B.E.; Kauffman, J.B. Bird communities following high-severity fire: Response to single and repeat fires in a mixed-evergreen forest, Oregon, USA. For. Ecol. Manag. 2009, 257, 1496-1504. [CrossRef]

28. Hutto, R.L.; Bond, M.L.; Dellasala, D.A. Using Bird Ecology to Learn About the Benefits of Severe Fire. In The Ecological Importance of Mixed-Severity Fires: Nature's Phoenix; DellaSala, D.A., Hanson, C.T., Eds.; Elsevier: Waltham, MA, USA, 2015; pp. 55-88.

29. Bond, M.L. Mammals and Mixed- and High-severity Fire. In The Ecological Importance of Mixed-Severity Fires: Nature's Phoenix; DellaSala, D.A., Hanson, C.T., Eds.; Elsevier: Waltham, MA, USA, 2015; pp. 89-117.

30. Buchalski, M.R.; Fontaine, J.B.; Heady, P.A., III; Hayes, J.P.; Frick, W.F. Bat response to differing fire severity in mixed-conifer forest, California, USA. PLoS ONE 2013, 8, e57884. [CrossRef]

31. Kulakowski, D.; Veblen, T.T. Bark Beetles and High-Severity Fires in Rocky Mountain Subalpine Forests. In The Ecological Importance of Mixed-Severity Fires: Nature's Phoenix; DellaSala, D.A., Hanson, C.T., Eds.; Elsevier: Waltham, MA, USA, 2015; pp. 149-174.

32. Jackson, B.K.; Sullivan, S.M.P.; Baxter, C.V.; Malison, R.L. Stream-Riparian Ecosystems and Mixed- and High-Severity Fire. In The Ecological Importance of Mixed-Severity Fires: Nature's Phoenix; DellaSala, D.A., Hanson, C.T., Eds.; Elsevier: Waltham, MA, USA, 2015; pp. 118-148.

33. Dudley, J.G.; Saab, V.A. Home Range Size of Black-Backed Woodpeckers in Burned Forests of Southwestern Idaho. West. N. Am. Nat. 2007, 67, 593-600. [CrossRef]

34. Saab, V.A.; Russell, R.E.; Dudley, J.G. Nest Densities of Cavity-Nesting Birds in Relation to Postfire Salvage Logging and Time Since Wildfire. Condor 2007, 109, 97. [CrossRef]

35. Hanson, C.T.; North, M.P. Postfire Woodpecker Foraging in Salvage-Logged and Unlogged Forests of the Sierra Nevada. Condor 2008, 110, 777-782. [CrossRef]

36. Saab, V.A.; Russell, R.E.; Dudley, J.G. Nest-site selection by cavity-nesting birds in relation to postfire salvage logging. For. Ecol. Manag. 2009, 257, 151-159. [CrossRef]

37. Bond, M.; Lee, D.E.; Siegel, R.B.; Ward, J.P. Habitat Use and Selection by California Spotted Owls in a Postfire Landscape. J. Wildl. Manag. 2009, 73, 1116-1124. [CrossRef]

38. Bond, M.L.; Bradley, C.; Lee, D.E.; Lee, D. Foraging habitat selection by California spotted owls after fire. J. Wildl. Manag. 2016, 80, 1290-1300. [CrossRef]

39. Baker, W.L. Restoring and managing low-severity fire in dry-forest landscapes of the western USA. PLoS ONE 2017, 12, e0172288. [CrossRef]

40. Bradley, C.M.; Hanson, C.T.; DellaSala, D.A. Does increased forest protection correspond to higher fire severity in frequent-fire forests of the western USA? Ecosphere 2016, 7, e01492. [CrossRef]

41. Miller, J.D.; Thode, A.E. Quantifying burn severity in a heterogeneous landscape with a relative version of the delta Normalized Burn Ratio (dNBR). Remote Sens. Environ. 2007, 109, 66-80. [CrossRef]

42. Holden, Z.A.; Morgan, P.; Hudak, A.T. Burn severity of areas reburned by wildfires in the Gila National Forest, New Mexico, USA. Fire Ecol. 2010, 6, 77-85. [CrossRef]

43. Cansler, C.A.; McKenzie, D. How Robust Are Burn Severity Indices When Applied in a New Region? Evaluation of Alternate Field-Based and Remote-Sensing Methods. Remote Sens. 2012, 4, 456-483. [CrossRef]

44. Miller, J.D. Patterns and Trends in Burned Area and Fire Severity from 1984 to 2010 in the Sierra De San Pedro Mártir, Baja California, Mexico. Fire Ecol. 2016, 12, 52-72. 
45. Kemp, K.B.; Higuera, P.E.; Morgan, P. Fire legacies impact conifer regeneration across environmental gradients in the U.S. northern Rockies. Landsc. Ecol. 2016, 31, 619-636. [CrossRef]

46. Steel, Z.L.; Koontz, M.J.; Safford, H.D. The changing landscape of wildfire: Burn pattern trends and implications for California's yellow pine and mixed conifer forests. Landsc. Ecol. 2018, 33, 1159-1176. [CrossRef]

47. Stevens-Rumann, C.; Kemp, K.B.; Higuera, P.E.; Harvey, B.J.; Rother, M.T.; Donato, D.C.; Morgan, P.; Veblen, T.T. Evidence for declining forest resilience to wildfires under climate change. Ecol. Lett. 2018, 21, 243-252. [CrossRef]

48. Picotte, J.J.; Peterson, B.; Meier, G.; Howard, S.M. 1984-2010 trends in fire burn severity and area for the conterminous US. Int. J. Wildland Fire 2016, 25, 413. [CrossRef]

49. Zar, J.H. Biostatistical Analysis, 5th ed.; Prentice Hall: Upper Saddle River, NJ, USA, 2010.

50. Shatford, J.P.A.; Hibbs, D.E.; Puettmann, K.J. Conifer regeneration after forest fire in the Klamath-Siskiyous: How much, how soon? J. For. 2007, 105, 139-146.

51. Haire, S.L.; McGarigal, K. Effects of landscape patterns of fire severity on regenerating ponderosa pine forests (Pinus ponderosa) in New Mexico and Arizona, USA. Landsc. Ecol. 2010, 25, 1055-1069. [CrossRef]

52. Chambers, M.E.; Fornwalt, P.J.; Malone, S.L.; Battaglia, M.A. Patterns of conifer regeneration following high severity wildfire in ponderosa pine-Dominated forests of the Colorado Front Range. For. Ecol. Manag. 2016, 378, 57-67. [CrossRef]

53. Hanson, C.T. Landscape heterogeneity following high-severity fire in California's forests. Wildl. Soc. Bull. 2018, 42, 264-271. [CrossRef]

54. Leiberg, J.B. Forest Conditions in the Northern Sierra Nevada, California. USDI Geological Survey; Professional Paper No. 8; U.S. Government Printing Office: Washington, DC, USA, 1902.

55. Hanson, C.T. Post-Fire Management of Snag Forest Habitat in the Sierra Nevada. Ph.D. Thesis, University of California at Davis, Davis, CA, USA, 2007.

56. Perry, D.A.; Hessburg, P.F.; Skinner, C.N.; Spies, T.A.; Stephens, S.L.; Taylor, A.H.; Franklin, J.F.; McComb, B.; Riegel, G. The ecology of mixed severity fire regimes in Washington, Oregon, and Northern California. Forest Ecol. Manag. 2011, 262, 703-717. [CrossRef]

57. Baker, W.L. Implications of spatially extensive historical data from surveys for restoring dry forests of Oregon's eastern Cascades. Ecosphere 2012, 3, 1-39. [CrossRef]

58. Leiberg, J.B. Southern part of Cascade Range Forest Reserve. In Forest Conditions in the Cascade Range Forest Reserve, Oregon; Langille, H.D., Plummer, F.G., Dodwell, A., Rixon, T.F., Leiberg, J.B., Eds.; Professional Paper No. 9; U.S. Geological Survey; U.S. Government Printing Office: Washington, DC, USA, 1903; pp. $229-289$.

59. Williams, M.A.; Baker, W.L. Spatially extensive reconstructions show variable-severity fire and heterogeneous structure in historical western United States dry forests. Glob. Ecol. Biogeogr. 2012, 21, 1042-1052. [CrossRef]

60. Dodge, I.R. The Black Hills: A Minute Description of the Routes, Scenery, Soil, Climate, Timber, Gold, Geology, Zoology, etc.; Miller, J., Ed.; Kessinger Publishing: New York, NY, USA, 1876.

61. Morgan, P.; Heyerdahl, E.K.; Miller, C.; Wilson, A.M.; Gibson, C.E. Northern Rockies pyrogeography: An example of fire atlas utility. Fire Ecol. 2014, 10, 14-30.

62. Morgan, P.; Hudak, A.T.; Wells, A.; Parks, S.A.; Baggett, L.S.; Bright, B.C.; Green, P. Multidecadal trends in area burned with high severity in the Selway-Bitterroot Wilderness Area 1880-2012. Inter. J. Wildland Fire 2017, 26, 930-943. [CrossRef]

63. Harvey, B.J.; Donato, D.C.; Turner, M.G. Drivers and trends in landscape patterns of stand-replacing fire in forests of the US Northern Rocky Mountains (1984-2010). Landsc. Ecol. 2016, 31, 2367-2383. [CrossRef]

64. Owen, S.M.; Sieg, C.H.; Meador, A.J.S.; Fulé, P.Z.; Iniguez, J.M.; Baggett, L.S.; Fornwalt, P.J.; Battaglia, M.A. Ponderosa pine regeneration in high-severity burn patches. For. Ecol. Manag. 2017, 405, 134-149. [CrossRef]

65. Yue, X.; Mickley, L.J.; Logan, J.A.; Kaplan, J.O. Ensemble projections of wildfire activity and carbonaceous aerosol concentrations over the western United States in the mid-21st century. Atmos. Environ. 2013, 77, 767-780. [CrossRef]

66. McKenzie, D.; Littell, J.S. Climate change and the eco-hydrology of fire: Will area burned increase in a warming western USA? Ecol. Appl. 2017, 27, 26-36. [CrossRef]

67. Parks, S.A.; Holsinger, L.M.; Miller, C.; Parisien, M.A. Analog-based fire regime and vegetation shifts in mountainous regions of the western US. Ecography 2018, 41, 910-926. [CrossRef] 
68. Stevens, J.T.; Collins, B.M.; Miller, J.D.; North, M.P.; Stephens, S.L. Changing spatial patterns of stand-replacing fire in California conifer forests. For. Ecol. Manag. 2017, 406, 28-36. [CrossRef]

69. Collins, B.M.; Stevens, J.T.; Miller, J.D.; Stephens, S.L.; Brown, P.M.; North, M.P. Alternative characterization of forest fire regimes: Incorporating spatial patterns. Landsc. Ecol. 2017, 32, 1543-1552. [CrossRef]

70. Donato, D.C.; Campbell, J.L.; Franklin, J.F. Multiple successional pathways and precocity in forest development: Can some forests be born complex? J. Veg. Sci. 2012, 23, 576-584. [CrossRef]

71. Miller, J.D.; Safford, H.D.; Welch, K.R. Using one year post-fire fire severity assessments to estimate longer-term effects of fire in conifer forests of northern and eastern California, USA. For. Ecol. Manag. 2016, 382, 168-183. [CrossRef]

72. Savage, M.; Mast, J.N. How resilient are southwestern ponderosa pine forests after crown fires? Can. J. For. Res. 2005, 35, 967-977. [CrossRef]

73. Tepley, A.J.; Thompson, J.R.; Epstein, H.E.; Anderson-Teixeira, K.J.; Anderson-Teixeira, K.J. Vulnerability to forest loss through altered postfire recovery dynamics in a warming climate in the Klamath Mountains. Glob. Chang. Boil. 2017, 23, 4117-4132. [CrossRef]

74. Swanson, M.E.; Franklin, J.F.; Beschta, R.L.; Crisafulli, C.M.; DellaSala, D.A.; Hutto, R.L.; Lindenmayer, D.B.; Swanson, F.J. The forgotten stage of forest succession: Early-successional ecosystems on forested sites. Front. Ecol. Environ. 2011, 9, 117-125. [CrossRef]

75. DellaSala, D.A.; Hanson, C.T. (Eds.) The Ecological Importance of Mixed Severity Fire: Nature's Phoenix; Elsevier: Waltham, MA, USA, 2015.

76. Phalan, B.T.; Northrup, J.M.; Yang, Z.; Deal, R.L.; Rousseau, J.S.; Spies, T.A.; Betts, M.G. Impacts of the Northwest Forest Plan on Forest Composition and Bird Populations. Proc. Natl. Acad. Sci. USA 2019, 116, 3322-3327. [CrossRef]

77. Cohen, J. Preventing disaster: Home ignitability in the wildland-urban interface. J. For. 2000, 98, 15-21. [CrossRef]

78. Moritz, M.A.; Batllori, E.; Bradstock, R.A.; Gill, A.M.; Handmer, J.; Hessburg, P.F.; Leonard, J.; McCaffrey, S.; Odion, D.C.; Schoennagel, T.; et al. Learning to coexist with wildfire. Nature 2014, 515, 58-66. [CrossRef]

79. Schoennagel, T.; Balch, J.K.; Brenkert-Smith, H.; Dennison, P.E.; Harvey, B.J.; Krawchuk, M.A.; Mietkiewicz, N.; Morgan, P.; Moritz, M.A.; Rasker, R.; et al. Adapt to more wildfire in western North American forests as climate changes. Proc. Natl. Acad. Sci. USA 2017, 114, 4582-4590. [CrossRef] 